Grand Valley State University

ScholarWorks@GVSU

2016

\title{
I Want to be the Inquiry Guy! How Research Experiences for Teachers Change Beliefs, Attitudes, and Values about Teaching Science as Inquiry
}

\author{
Deborah Herrington \\ Grand Valley State University, herringd@gvsu.edu \\ Senetta F. Bancroft \\ Grand Valley State University \\ Molly M. Edwards \\ Grand Valley State University \\ Caroline J. Schairer \\ Grand Valley State University
}

Follow this and additional works at: https://scholarworks.gvsu.edu/com_articles

Part of the Chemistry Commons, and the Science and Mathematics Education Commons

\section{ScholarWorks Citation}

Herrington, Deborah; Bancroft, Senetta F.; Edwards, Molly M.; and Schairer, Caroline J., "I Want to be the Inquiry Guy! How Research Experiences for Teachers Change Beliefs, Attitudes, and Values about Teaching Science as Inquiry" (2016). Peer Reviewed Articles. 15.

https://scholarworks.gvsu.edu/com_articles/15

This Article is brought to you for free and open access by the School of Communications at ScholarWorks@GVSU. It has been accepted for inclusion in Peer Reviewed Articles by an authorized administrator of ScholarWorks@GVSU.For more information, please contact scholarworks@gvsu.edu. 
I Want to be the Inquiry Guy! How Research Experiences for Teachers Change Beliefs, Attitudes, and Values about Teaching Science as Inquiry 


\begin{abstract}
This qualitative study examined how and why a research experiences for teachers (RET) influenced middle and high school science teachers' beliefs, attitudes, and values about teaching science as inquiry. Changes teachers reported after participating in the RET ranged from modifying a few lessons (belief change) to a comprehensive revision of what and how they taught to better reflect inquiry (attitude change). Some teachers who described comprehensively changing their instruction also described implementing actions meant to change science education within their respective schools, not just their own classrooms (value change). We present how and why teachers went about changes in their practices in relation to the researcher created teacher inquiry beliefs system spectrum (TIBSS). The TIBSS conceptualizes the range of changes observed in participating teachers. We also describe the features of the RET and external factors, such as personal experiences and school contexts, that teachers cited as influential to these changes.
\end{abstract}

Keywords: professional development; research experiences for teachers; science teacher beliefs, attitudes, and values 
I Want to be the Inquiry Guy! How Research Experiences for Teachers Change Beliefs, Attitudes, and Values about Teaching Science as Inquiry

\section{Introduction}

Well-designed professional development (PD) programs are an effective way to deliver authentic scientific experiences to teachers and ultimately reform classroom instruction (Supovitz \& Turner, 2000). Wilson (2013) describes effective PD programs as ones that: (i) focus on specific content; (ii) engage teachers in active learning; (iii) enable the collective participation of teachers (sometimes administrators); (iv) provide coherence (aligned with other school policy and practice); (v) are sufficient in duration (both in intensity and contact hours) (vi) employ activities that are close to practice; (vii) consider participants' physical and psychological comfort; (viii) immerse teachers in inquiry experiences and use inquiry teaching models; (ix) use curriculum materials that are educative for teachers and students; and (x) provide direct instruction in teaching innovative materials. Research experiences for teachers (RETs), while primarily delivering the eighth feature described by Wilson (2013) through immersing teachers in inquiry, can also be designed to include many of the other features she outlines as essential to effective PD. The benefits and effectiveness of RETs have been previously reported (Blanchard, Southerland, \& Granger, 2009; Dubner et al., 2001; Pop, Dixon, \& Grove, 2010; Westerlund, García, Koke, Taylor, \& Mason, 2002). However, identifying and explicating (theoretically and practically) how effective RETs change science teachers' knowledge, feelings, and practices about inquiry-based instruction remains a challenge for the science education community (Enderle et al., 2014; Pop et al., 2010). 
Our study responds to this challenge with the purpose of characterizing how and why an RET, the first of three core experiences in a two and half year intensive PD program, influence middle and high school science teachers' beliefs, attitudes, and values in relation to their classroom instruction.

\section{Literature Review and Theoretical Framework}

Teachers' willingness to reform their classroom instruction as they participate in PD depends on their preconceived beliefs, the opportunities provided by the PD program, the context of these PD opportunities, and the school setting they return to (Anderson, 2002; Lotter, Harwood, \& Bonner, 2007). Using an apprenticeship model, an RET can shape teacher beliefs and affect related to inquiry instruction by offering them active and immersive involvement in science practices (Pop et al., 2010; Russell \& Hancock, 2007). A fundamental goal of RETs is to help teachers to better communicate real-world use of science practices to their students through classroom instruction (Dubner et al., 2001). Thus, PD programs that adopt RETs to transform K-12 science teachers' understanding and practice of inquiry have the potential to be pivotal in achieving the Next Generation Science Standards' (NGSS) vision of science education in which inquiry-based, scientific practices are embedded in instruction (NGSS Lead States, 2013). Further, transforming teacher beliefs is fundamental to enduringly transforming their understanding and practice of inquiry in their classroom.

Generally, a belief is a highly influential, personal construct that determines an individual's actions (Bandura, 1986; Pajares, 1992; Rokeach, 1968). Similarly, in science education research, teacher beliefs have been shown to be a strong predictor of their dispositions towards implementation of inquiry-based practices (Haney, Czerniak, \& 
Lumpe, 1996). However, although enduringly changing traditional beliefs about teaching and learning formed over a lifetime is possible, it is challenging (Pajares, 1992; Nespor, 1987). This study sought to understand changing teacher beliefs about inquiry within the context of an RET and go one step further by also examining how teacher attitudes and values about teaching science as inquiry can change as result of participation in an RET.

Beliefs, attitudes, and values are distinct constructs that are neither interchangeable nor should be indistinguishably combined. Researchers who have explored the concept of beliefs in general acknowledge that beliefs are highly idiosyncratic constructs that are challenging to systematically and systemically understand (Abelson, 1979; Ajzen, 1988; Fishbein \& Ajzen, 1975; Lewis, 1990; Nisbitt \& Ross, 1980; Rokeach, 1960; 1968; 1979). Although beliefs can be conceptualized as diffuse (Ajzen, 1988; Fishbein \& Ajzen, 1975), researchers who have more specifically explored teachers' beliefs subscribe to conceptualizations characterizing beliefs as discrete constructs interconnected within a larger, organized schema or system (Crawford, 2007; Kagan, 1992; Nespor, 1987; Pajares, 1992; Richardson, 1996) where core beliefs, unlike peripheral beliefs, can be extremely difficult to change (Pajares, 1992; Peterman, 1991). We use Pajares's (1992) definition of a belief as “an individual's judgment of the truth or falsity of a proposition, a judgment that can only be inferred from a collective understanding of what human beings say, intend, and do" (p. 316) to frame our teachers' beliefs about inquiry. We also use Rokeach's $(1960 ; 1968 ; 1979)$ discrete notion of beliefs, which he organized within a larger belief system of attitudes and values as shown in Figure 1. Additionally, drawing from Rokeach's (1968) work, we 
acknowledge that beliefs have cognitive, affective, and behavioral components (see Figure 1).

\section{Insert Figure 1 here}

Thus, we do not conceptualize teachers' inquiry related knowledge (cognitive component), feelings (affective component), or practices (behavioral component) as separate from their beliefs about inquiry.

Further, as shown in Figure 1, when a set of beliefs holistically organizes around a specific context and enduringly predisposes the individual to action in some preferential way within that context, an attitude has been developed. As a result, our conceptualization of teacher attitudes about inquiry-based instruction extends beyond how they feel about this type of instruction, for example "it is frustrating to get students to formulate testable questions," which is how the term attitude is typically used in science education (Koballa \& Crawley, 1985; Zacharia, 2003). Instead, we conceptualize an attitude change towards inquiry to be exhibited by expressions that indicate an enduring increase in preference to enact behaviors that reflect their beliefs about inquiry. Additionally, for this increased preference to lead to action towards goal attainment sufficient guidance and emotional intensity related to the goal and the context within which the goal is to be achieved must also be present (Rokeach, 1968; Schwartz, 1994).

Values, unlike beliefs and attitudes, give birth to conscious, personal goals and simultaneously act as evaluative, comparative and judgmental filters enabling an individual to replace predisposition to act with an imperative for action (Rokeach, 1968; Schwartz, 1994). Values therefore serve as internal drives for the overarching behaviors 
and worldviews that become personally or socially preferable and acceptable to an individual (Rokeach, 1973). This role as a central driver for action that does not require external guidance and a threshold emotional intensity is a dimension that discriminates the value construct from the constructs of beliefs and attitudes (Fine \& Glasser, 1996; Rokeach, 1968; 1973). There has been some research on teacher attitude towards inquiry teaching both as feelings and as intentions towards enactment of inquiry related behavior (Damnjanovic, 1999; Marlow \& Stevens, 1999; Zacharia, 2003). Further, although values tend to be extremely stable, people can learn to make decisions favoring one value over another (Rokeach, 1973). Ultimately, the means an individual feels comfortable employing for attainment of their goals is linked and limited to the intensely personal dimension of their values (Gupta, 2012). However, the exploration of how effective PD may go even further and change science teachers' values is not well examined (Hawkey, 1996; Helms, 1998; Mansour, 2008).

The research on how RETs influence teacher practice is limited (Enderle et al., 2014) and there are virtually no explorations of how RETs or effective PD may change not only science teachers' beliefs and attitudes, but also their values about science instruction. We explore how teacher participation in an RET focused on inquiry-based instruction affects teachers' belief, attitudes, and values. The research questions guiding this study were:

1) How, if at all, does the PD's RET change participating teachers' beliefs, attitudes, and values about of inquiry-based science instruction?

2) What are the key features of the PD's RET participating teachers identify as influential to changes in their beliefs, attitudes, and values? 
3) What factors unrelated to the PD's RET do participating teachers identify as influential to changes in their beliefs, attitudes, and values?

\section{Methods}

\section{Context of Study}

Participants. Thirteen science teachers from middle and high schools in the west Michigan area participated in the RET. Middle and high school teachers of various science subjects entered the PD program with a broad range of teaching experience. A more detailed description of participating teachers and their school context is shown in Table 1.

\section{$\underline{\text { Insert Table } 1 \text { here }}$}

Features of effective RETs include: lasting at least 6 weeks, usually during the summer; matching participants with research groups based on their interests; facilitating teachers' translation of the RET experience through preparation of materials for classroom use; developing community or networks among participants; and engaging sustained follow-ups with teachers about classroom implementation over the course of the subsequent academic year (Russell \& Hancock, 2007). This sustained follow-up is key to positive outcomes of RETs as well as participant satisfaction. This PD's RET included all of these features. A brief outline of the RET design is shown in Table 2.

\section{$\underline{\text { Insert Table } 2 \text { here }}$}

\section{Data Collection}

Semi-structured, face-to-face interviews were conducted with each participating teacher prior to the RET (pre-RET) and one year after the start of the RET (post-RET). Both interviews used open-ended questions and were approximately one hour long. 
Interviews, particularly those using open-ended questions, have been demonstrated to be an effective and crucial method to eliciting science teacher beliefs (Harwood, Hansen, \& Lotter, 2006; Luft \& Roehrig, 2007). Further, interviewing is one of the few data collection methods that allows researchers to explore how individuals organize and make meaning of their beliefs (Kagan, 1992; Merriam, 2002; Patton, 2002). However, interview data have their limitations due to the possibility of distorted responses stemming from personal biases, recall error, reactivity of the interviewee to the interviewer, and self-serving purposes (Patton, 2002). Open-ended questions and minimal prompting from the interviewer both verbally and through body language were used in an attempt to reduce the latter two limitations. With both the strengths and limitations of interviewing in mind, within this qualitative study we assume that the thoughts/beliefs of the participating teachers are "meaningful, knowable, and able to be made explicit" (Patton, 2002, p. 341) and will, therefore, very likely yield new and worthwhile knowledge (Kvale, 1994).

The pre-RET interview explored each teacher's prior experiences with science as K-16 students and as science education students, their motivation for seeking out PD, and their science classroom practices. Some questions posed to teachers in the pre-RET interview included:

- I want you to briefly describe to me your experience learning science as a student. What were your science classes like where you learned science?

- What teaching strategies do you typically use in your classroom?

- What are your goals for your students? What do you want them to learn? 
- What are some barriers that might prevent you from implementing inquiry-based instruction in your classroom?

Post-RET interviews focused on how the RET influenced teachers' knowledge, feelings, and practices with respect to their teaching and student learning. The post-RET interview was structured around the context of asking teachers to describe changes in their ideas about teaching and learning or any changes in their teaching practices in relation to the RET. That is, the post-RET interview was situated around the context of change in teacher instruction. Some questions posed to teachers during the post-RET interview included:

- If you could, reflect a little bit on your experience in the program so far?

- Can you describe any changes you have seen in your students this year?

- Were you able to use some of the activities that you modified last summer? Can you talk a little more about the ones that you used and your experience with them?

- What are the specific ways you have modeled scientific inquiry since the research experience?

- Here are the science and engineering practices from NGSS. Could you look at those and describe some specific ways that you see your research experience from last summer overlapping with these?

Complementary to our use of researcher created open-ended questions, the pre-RET and post-RET interview protocols concluded with each teacher engaging with the Inquiry Teaching Beliefs instrument (ITB, Harwood et al., 2006). 
The ITB instrument is anchored in phenomenographic epistemology and designed around the assumption that teachers have internal models of inquiry and base their classroom practices on these internal models (Harwood et al., 2006). The ITB was designed to elicit science teachers' internal models of inquiry through a card sorting and interview process (Harwood et al., 2006). When engaging with the ITB, teachers were presented with 17 " x 17 " board and 19 cards. The 19 cards include:

- 1 classroom card (representing an inquiry-based instruction science classroom)

- 8 cards with activities defined as inquiry described (example activity: Students using evidence to defend their conclusions)

- 6 cards with activities defined as non-inquiry described (example activity: Students completing worksheets)

- 4 cards with activities defined as neutral described (example activity: Students asking questions)

The classroom card was glued to the center of the board. Teachers were asked to place the remaining 18 cards on the board with the cards they perceived as most supportive of inquiry instruction closest to the classroom card and the cards least supportive of inquiry instruction farthest from the classroom card. Note, all of the activity cards looked the same so teachers were not aware of which activities were classified as inquiry, neutral, or non-inquiry. After teachers had constructed their models, they were then asked to explain the rationale behind the placement of each card and their overall arrangement of cards around the classroom card. Teachers' explanations for placement of these cards were included in our data analysis. 


\section{Data Analysis}

Interviews were transcribed in Word using intelligent verbatim transcription. Intelligent verbatim transcription was used only if a word or short phrase distracted from a reader being able to understand a thought. More specifically, we only deviated from verbatim transcription to intelligent verbatim transcription to modify expressions such as "um" when overused, obvious grammatical errors, and very rarely inarticulate phrases as the teacher verbally struggled to express a thought.

Pre-RET. To gain insight into the general characteristics of the participating teachers before they engaged in the RET, we read through the pre-RET interviews to identify broad themes with respect to teachers' motivations for pursuing the PD program, what teachers knew about inquiry, and whether or how teachers used inquiry-based instruction in their classrooms.

Post-RET. Transcribed post-RET interviews were uploaded into the computer assisted qualitative data analysis software Dedoose (Version 5.0.11). A priori codes were determined and operationalized using science education literature about teacher beliefs and inquiry; much of this literature was cited in our introduction and literature review sections. A constant comparative method was used to complete the data analysis where a priori codes were refined --which included the introduction of sub-codes-- and redefined (see the appendix for finalized operationalized codes). The constant comparative process began with three coders independently coding an interview with the a priori codes. After independently coding the first interview, the three coders discussed similarities and differences in their coded text. The discussion was used to establish inter-rater reliability as well as determine the need to refine or redefine codes. This process was repeated with 
two more interviews. After the third interview, no refinement or redefinitions were needed and the codes and sub-codes were finalized. After comparing the coded text of the three interviews, we found $70 \%$ of statements were similarly coded. The remaining statements were typically coded under the same parent code, but with a different or no sub-code applied. These differences were resolved in our discussions. The remaining interviews were coded independently by two coders and any differences continued to be resolved between the coders through discussions. After coding each interview, coders placed teachers in one of the following categories on the teacher inquiry beliefs system spectrum (TIBSS): no change; belief change; attitude change; or value change. The categories and criteria (see Figure 2) for each category for the TIBSS was developed from our conceptualization of teacher beliefs described in the literature review.

\section{Insert Figure 2 here}

During the analysis of the post-RET interview data, it emerged that there were a subset of teachers who had all of the characteristics of an attitude change and also expressed plans to encourage their colleagues to make changes. However, unlike the teachers in the value change category, these plans had not yet resulted in related actions. Therefore, as shown in Figure 2, a fifth category of emerging value change was added to the TIBSS to categorize these teachers who seemed to be on the verge of a value change. Finally, within Dedoose, frequency counts for codes and sub-codes were cross-tabulated with the categories of: belief change; attitude change; emerging value; and value change. 


\section{Results}

\section{Pre-RET}

In pre-RET interviews all teachers expressed some theoretical understanding of inquiry. However, teachers also consistently described a recognition of gaps in their theoretical knowledge, a desire to be a more effective teacher, and a struggle to translate their theoretical knowledge into practices they believed consistently aligned well with inquiry-based practices. In the following statement, Teacher 10 nicely captures all participating teachers' recognition of possible gaps in their knowledge of inquiry and the struggle to translate their knowledge into practice, which together served as a primary motivation for pursuing the PD program:

... I've had exposure to this is what I think inquiry is... But not exposure tohere's some real activities, here's something that...really qualifies as that. But then even when you're given [inquiry resources] you're like, oh yeah that's cool, but then you think how do you even figure out how to do that yourself? You know what I mean, you're still at that point where, how do you get to that point where, you're confident to develop it yourself?

Nine of the thirteen teachers, Teachers 1-6, 9-10, and 12, indicated the goals they hoped to achieve for their students through pursuing this PD was to help their students think critically and/or like scientists. The remaining four teachers, Teachers 7, 8, 11, and 13, indicated they hoped to help their students develop skills that would help them to be successful at life in general. When asked about their use of inquiry or classroom practices, three teachers, Teachers 2,4 , and 9 were able to give at least one, but no more 
than three specific examples of an inquiry-based activity they used in their classrooms. Teacher 9, for example explains:

I would say a lot of- at least in my classroom things that I consider inquiry in a lot of cases are not labs, they're more activity or problem solving. I was getting really sick of trying to go through the parts of the brain and what they do, because it was a very rote memory kind of thing and that was driving me nuts, so I introduced the idea and I had them gather some information and made sense to them, and in a chart form so they could say "this section of the brain, this is their main function," that kind of thing. And then the next day I gave them a big piece of paper and said, "I need you to draw the brain, and I want it colorful and lovely," you know, just because I wanted them- they like that kind of thing. Then I put up on the board- a person walked into the room and they saw this and they smelled this and they determined something was wrong, so they turned and they ran out of the room. And I said, "Now I want you, with arrows, to tell me what went into the brain and what went out." It wasn't going to be perfectly accurate, scientifically speaking, but they had to think, well let's see, they walked into the room, they smelled something- that means it was this section of the brain. ... There was no lab per se, but it was very much something where they had to work through... All other teachers spoke in generalities or within a theoretical context when speaking about their knowledge or use of inquiry, offering no descriptions of specific ways in which they used inquiry. For example Teacher 5 states:

Even just coming up with a great question, it would be fun, like I have this idea of just letting them kind of roll with it, and then going from there, like they come up 
with a question, and they go to test it, and they realize, oh my gosh, my question is way too broad, how am I going to do this? And so, starting out with it with very limited instruction would be very cool, and then to see how they could then refine their practice, as we go, and even give them more specific guidelines, so they get more of a problem solving activity. I just don't know how to incorporate that with the actual curriculum I have to teach. (Teacher 5)

Therefore, within our framework for analyzing the post-RET interviews, any expression in which the teacher is able to explicate specific knowledge, feelings, and behaviors related to inquiry that represents a change for them was considered an indication of a change in teacher beliefs. Given that the post-RET interview protocol was within the context of change of instruction in relation to the RET, the findings from the coded postRET interviews are representative of how teachers beliefs about teaching and learning science changed.

\section{Post-RET}

As shown in Table 3, all participating teachers had some degree of a belief change after participating in the RET. For example, Teacher 13's statements reflected a better understanding of inquiry-based science instruction and some related changes in his classroom practice.

He states:

I think that recognizing and I think some of that came from the [material adaption feature of the RET], realizing I don't need to start completely new with it and completely revise and create entire new lessons from everything I do, but can take some of it and modify a piece of it or- and I think definitely I've seen myself do 
that a lot more.... A lot of the steps that we just talked about [NGSS science practices] ...that's something I've tried to incorporate this year, trying to pull in one or two of these steps...

Teacher 13's mixed feelings and motivation about his job and motivation for change (see his statement in Table 3) seemed to contribute to the limited changes to his instruction. Teacher 13 was the only teacher who had such mixed beliefs related to inquiry-based instruction and who described only partial changes in how he approached classroom instruction after the RET. In contrast to only three teachers describing ways in which they specifically enacted inquiry in their classroom pre-RET, all teachers were able to explain at least three specific inquiry based strategies they had enacted in their classrooms postRET. Further, the ability of all teachers to explain specific ways in which their instructional practices changed post-RET points towards teachers' actually experiencing change rather than just providing responses stemming from biases or reactivity to the interviewer.

\section{$\underline{\text { Insert Table } 3 \text { here }}$}

Most participating teachers ( 7 out of 13) statements indicated a change in attitude towards inquiry-based practices in their classroom. These teachers stated specific ways in which they tried to incorporate inquiry, to varying extents, into everything they taught. For example Teacher 5 states:

So, it's been an interesting challenge if I want to try to make things more inquiry based, to take pieces out to give students more freedom and flexibility, because it's pretty guided... I would now implement questioning strategies where they tell students, explain [and] I have them do some more experimental work first, to try 
to get their own opinions and background knowledge going, and then I have them go in and do reading after...

For Teachers 1,3, and 8 not only did they indicate completely overhauling their instruction to reflect inquiry, but they also stated plans to encourage their colleagues to make similar changes (see Table 3 for a representative statement). Teachers 2 and 4 shared all the characteristics of teachers with an attitude change, but had also begun collaborating with their colleagues to make similar changes in their practice (see Table 3 for a representative statement). A primary underlying difference for the behavior between teachers with an emerging value change and a value change seemed to be how quickly and to what extent their knowledge of inquiry-based instruction "clicked" with their ability to enact the related practices, which in turn seemed linked to their inquiryrelated pedagogical content knowledge (PCK). Teachers 3 and 4 help to highlight this underlying difference.

Teachers 3 and 4 are both males with more than 10 years of teaching experience, teaching the same high school physics curriculum in the same middle school. Teacher 3, who we placed in the emerging value change category, stated that at the beginning of the academic year following the RET he fell back on traditional ways of teaching, but the continued immersion in the PD during that year supported him enough and enabled him to finally "wrap his mind around" inquiry-based instruction. Teacher 3 describes his breakthrough moment this way:

About two thirds of the way through the year when I was doing the final part of my evaluation, collecting data on their conclusions I kind of had this "ah ha!" that I've pulled them in two different directions. And it finally clicked for me, the 
linking of the evidence and the claim. .... [students] have to make that connection that isn't obvious and in many cases it's not direct evidence, it's indirect evidence and so to explain how the indirect evidence proves the claim is kind of the most important part of that conclusion and then all of the other stuff is important as well. But I guess that is where it finally clicked for me that we have to give them examples of indirect evidence and show them how to link that to a claim...

It was only after this moment, which occurred late in the academic year following the RET, that he was able to move past his personal struggle to coherently connect the behavioral component of his beliefs about inquiry-based practices to the knowledge component. Teacher 3 goes on to describe a desire to have a greater focus on his students' learning as well as the desire to work with colleagues to influence their practices after this breakthrough moment.

In comparison to Teacher 3 , Teacher 4 who was categorized as having a value change, attributes a "knack for teaching," a tenacity to be the best teacher he can possibly be, and hard work for his relatively rapid integration of his knowledge of inquiry acquired from the RET into his practice. These attributes are highlighted when Teacher 4 states:

So, why not be the best at it that I can be? So, once I got the realization that this is really what I have to be doing because it's good for kids and it's good for science and it's good for a lot of things. Then it became a part of what I do....So everything that I'm hoping to get out of this I've already started to do. But I wanted to be better at it, step it up three or four notches- that little note that I read, you teach science a different way- I want to be that guy, I want to be the guy that 
teaches science a different way. I want to be the guy that when you walk in here you're scientists- I want them to go yeah, you're right, we are!

For Teacher 4 and the other two teachers with a value change, the cognitive and behavioral components of their inquiry-related beliefs "clicked" quickly compared to teachers in other TIBSS categories. This rapid integration seemed to precipitate an internal change that drove them to consistently and confidently choose to focus on student learning and a collaboration with colleagues that revolved around changing how science teaching and learning occurred in their daily work environment. This shift in internal drive and related actions seemed unique to the teachers who expressed what Teacher 4 called "a knack for teaching" and what we conceptualized as PCK. This made the frequency with which teachers in the different TIBSS categories stated concepts or actions related to behavioral, pedagogical, or knowledge about inquiry of interest. Table 4 provides representative statements for each type of concept/action as well as frequency counts by TIBSS group.

\section{$\underline{\text { Insert Table } 4 \text { here }}$}

Reviewing the types of statements teachers made as well as frequencies with which teachers in different TIBSS categories made these types of statements, highlighted some interesting differences between teachers in different categories with respect to how likely they were to talk about particular ideas. Given that there were a different number of teachers in each TIBSS group, to provide a more equitable comparison we compared the percentage of participating teachers within a given TIBSS category who made a given type of statement to the percentage of the statements the teachers in that TIBSS category account for under the code or sub-code being discussed. 
For example, all 13 teachers acknowledged increased knowledge of inquiry-based instruction and increased use of behavior that reflected inquiry-based practices. However, the five teachers (38\% of participating teachers) who had indications of an emerging value or value change were more likely to describe specific knowledge (56\% of all statements) and slightly more likely to describe enactment of inquiry-based practices (44\% of all statements) compared to teachers with an attitude or belief change. Additionally, these five teachers accounted for $73 \%$ of all coded statements reflecting PCK related to inquiry-based instruction. Teachers with emerging value or value changes were therefore more likely to describe specific ways in which they used PCK compared to teachers in the other categories. This trend made sense as these teachers described a depth and strength of the coherency in their integration of their knowledge, feelings, and actions related to inquiry-based practice that were absent from the teachers with a belief or an attitude change descriptions.

No matter teachers' placement on the TIBSS, by far and unsurprisingly given the primary purpose of an RET, the most influential feature of the RET cited was the opportunity to build a better understanding of how scientists work and produce knowledge. A more detailed list of the features teachers indicated as being influential, statements representative of how teachers contextualized the influence of each of these features, and the frequency of statements related to each feature is shown in Table 5.

\section{$\underline{\text { Insert Table } 5 \text { here }}$}

Two components of the weekly debriefing meetings, collaboration with teachers in the cohort and lessons on inquiry, were the next most cited influential feature of the RET. For the teacher with the belief change, collaboration with teachers was the feature 
he most frequently referred to as influential. The lessons on inquiry and the poster presentation were more likely to be cited by teachers with an emerging value or a value change as influential features. The material adaptation, which was also a component of the weekly debriefing meetings, was the least cited by teachers, and the only RET feature that was equally likely to be cited as influential by teachers across all TIBSS categories. However, how teachers cited this activity as influential was interesting. Across the attitude, emerging value, and value change categories teachers solely cited the materials adaption as helping them to make changes to their classroom activities, which aligned to the feature's primary intent. However, for Teacher 13, the teacher with the belief change, this feature was also cited as influential for allowing him to witness how his peers were implementing inquiry in their classroom. He states:

I felt once I started to work on my own on things I kind of wished we had more of that, because it was those actual, practical, doing those things and working on modifying and starting to do that with other people and getting ideas and seeing lots of other people work on those things, I think that started to help develop those skills...

Teacher 13's statement above also hints at his struggle with PCK; a struggle which emerged in several places in his interview. Teacher 13 was also the only teacher who had associated the most negative feelings about inquiry after the RET.

Teacher feelings about inquiry after experiencing the RET were overwhelmingly positive (see Table 6). Collectively there were 195 statements made about how they felt about inquiry in some aspect and $84 \%$ of these statements were positive, $4 \%$ were neutral, and $12 \%$ negative. Teacher 13 , the teacher in the belief change category was the 
most likely teacher to describe negative feelings about inquiry ( 11 of the 24 negative statements). Many of these negative statements related to difficulties with PCK and his school culture as well as trying to like/commit to his job as his earlier statement in Table 3 indicated.

\section{Insert Table 6 here}

\section{Discussion}

The teachers who experienced the greatest degree of change, a value change, were both males whose teaching experience on entry to the PD ranged from one year to more than 10 years. We view this as particularly important as the literature tells us beliefs tend to become more difficult to change with experience (Pajares, 1992); however, these results indicate that this RET meaningfully impacted teachers with a broad range of experience. It is also notable that teachers with indications of an emerging value or a value change exclusively taught at middle schools. A plausible explanation for this may be related to middle school students having more positive attitudes towards science compared to high school students (Gibson \& Chase, 2002) and are thus likely more engaged. More engaged students are, in turn, linked to teachers with increased willingness to take risks in their classrooms (Raudenbush et al., 1992).

All teachers indicated their knowledge of the characteristics of inquiry-based teaching and learning increased. However, teachers who had indications of an emerging value or a value change expressed a high integration of this knowledge into their PCK. PCK is an essential component of effective teaching (Abell, 2007) and is strongly correlated to teachers' ability to enact inquiry-related behavior (Park, Jang, Chen, \& Jung, 2011). By a factor of approximately 3, teachers with indications of a value change 
had a higher frequency of statements related to their PCK despite accounting for only $38 \%$ of teachers in the study. Evidence of this higher integration is also seen in the representative statements of each category on the TIBSS shown in Table 4. Moreover, teachers with a value change expressed their goals as educators in terms of a focus on their students', colleagues', and district's growth while teachers with a belief or attitude change were still focused on helping their students and developing themselves as effective educators. Further, how emerging value and value change teachers rationalize their focus on student learning and developing their habits of mind to reflect those of scientists seem to align well with Luft and Roehrig's (2007) reform-based profiles conceptualized within their Teacher Beliefs Interview framework.

The most frequently stated influential feature of this RET was better understanding of the scientific process. Teachers' high frequency of referencing this feature aligns with the primary purpose of this RET and RETs in general. Overall, the second most cited feature by teachers across all TIBSS categories was the weekly debriefing meetings. The collaborative aspect of these meetings, which included teachers sharing their experiences and listening to the experiences of their cohort teachers validated their own challenges conducting scientific research and contributed to their well-being. This finding supports previous identification of building community (Russel \& Hancock, 2007) and taking care of teachers' psychological comfort during PD (Wilson, 2013) as essential features of effective PD. The process of Teacher 13 witnessing the specific ways in which others modified their classroom activities to reflect inquiry-based practices as well as collaborating with them was one of the most highly influential features on his beliefs about inquiry-based instruction. This opportunity for 
peer instruction within the community created in the weekly debriefing meetings was one way this PD delivered the essential feature of providing direct instruction in teaching innovative materials (Wilson, 2013). Despite the influences of the RET on teachers' changed beliefs, it was also important to recognize that participating teachers had experiences outside of, both before and during, the RET that likely also influenced whether they had a belief, attitude, or value change or any change at all. Therefore, it was necessary for us to explore what other influences, outside the RET, teachers considered as influential to their motivation for changing their beliefs related to science instruction.

The teachers with emerging value or value changes were the most likely to describe experiences not directly related to the RET as influencing their instruction after the RET. These include teachers' lived experience as a student, which as a result seemed already well-integrated into their values about teaching and learning. For example, Teacher 4 states:

...for a poor kid time with people is a big deal. I grew up a poor kid, so time with people is a big part of what I go for. So I think it's been the whole program. The research experience definitely drove me, because I wanted every kid in this classroom to feel the success that I felt after my research experience.

Additionally, the removal of barriers by school districts/school administration seemed to be a more likely occurrence for emerging value or value change teachers. Teacher 1 states:

...maybe that's a district thing, I mean if we're getting rid of half of our year of science than I guess I don't need to be so concerned about hitting every single thing. And so I think that maybe that has something to do with it too, oh well you 
know this lab is going really well, we're going to extend this and skip this worksheet, so I think that that's probably part of it too.

The barriers removed or reduced by schools or districts were mostly related to reduced content and/or more time collaborate with other science teachers. This provided teachers with opportunities to be flexible with what they taught, when they taught it, and/or how they taught. When we consider that the teachers who showed the greatest extent of change on the TIBSS also were the most likely to cite personal or school related factors as influencing the degree of change that took place in their classroom practice, it reaffirms that a teacher's personal growth remains "an intensely private affair" (Kagan, 1992, p. 65). However, in spite of the highly personal nature of teacher belief, attitude, and value change, effective PD such as this RET can give teachers a platform to secure meaningful academic freedom within their classrooms and even help them assume leadership roles within those schools and districts (Halverson \& Clifford, 2013).

\section{Conclusions}

Although this study involved a small group of teachers $(N=13)$ and looked at a single RET, this study suggested that a well-designed RET can reform the teaching practices. This RET reformed the instructional practices in science teachers with a broad range of teaching experience and who teach various sciences. Not only was the RET itself key to influencing teacher practice, but the weekly debriefing meetings and year of follow-up that collectively created community, attended to teachers well-being, and guided teachers through the process of adapting of two of their existing classroom activities helped all teachers translate their research experience into their classroom practice. The attendance to teacher pedagogy has been identified as key to teachers being 
able to enact their changed knowledge and emotions about reformed instruction into reformed classroom practices (Enderle et al., 2014). Further, it seems necessary to nurture PCK (whether teachers bring strong PCK with them or it is built into the PD) so teachers feel enabled and empowered to reform practices in their classrooms and even the practices of their colleagues. However, the level of change or risk teachers seemed willing to take in changing their classrooms and school seem related to the school context/environment they return to after the RET as well as highly personal attributes. Whatever PCK or personal attributes participating teachers brought with them, when the content they had to teach was reduced and time for collaboration with other science teachers was increased within their district, it also seemed the likelihood of their willingness to reform their practice also increased.

Further, as other studies have found (Lakin \& Wallace, 2015; Luft \& Roehrig, 2007) we found the interviewing process to be an effective method for capturing teachers' beliefs about teaching and learning science. Moreover, we found the TIBSS allowed us to not just frame in-service teachers' beliefs as their philosophies regarding the practice of teaching, but also frame how and to what extent teachers put their knowledge and feelings about inquiry-based practices into action. This included how they enacted (or intended to enact) their beliefs within their classroom and whether and in what context they chose to disseminate their knowledge about reformed instruction within and beyond their classrooms. Therefore, the TIBSS has the potential to offer researchers and PD developers a novel framework for evaluating the program impact on teachers and schools. 


\section{Future work}

This RET is the first of three core experiences that are primarily delivered in summer over 2.5 years. Follow up studies examining whether teacher beliefs, attitudes, and values related to inquiry-based instruction continue to evolve and how these changes relate with other evaluations of their instructional practices will be useful to understanding how long-term and multiple core PD experiences influence teachers belief systems. We plan to compare teachers' placement on the TIBSS with changes in their Reformed Teaching Observational Protocol (Sawada et al., 2002) scores and with the Teacher Beliefs Inventory (Luft \& Roehrig, 2007). Future interviews with teachers will also explicitly explore how, if at all, they have collaborated with colleagues in their school and/or district. This will help assess whether teachers who had indications of an emerging value carried through with their planned dissemination of change and whether teachers found to have a value change in this study sustained that change. 


\section{References}

Abell, S. (2007). Research on science teachers' knowledge. In S. Abell \& N. Lederman (Eds.), Handbook of research on science education (pp. 1105-1149). Mahwah, NJ: Lawrence Erlbaum.

Abelson, R. (1979) Differences between belief systems and knowledge systems. Cognitive Science, 3, 355-366.

Ajzen, I. (1988). Attitudes, personality, and behaviour. London, England: Open University Press.

Anderson, R. D. (2002). Reforming science teaching: What research says about inquiry. Journal of Science Teacher Education, 13(1), 1-12.

Bandura, A. (1986). Social foundations of thought and action: A social cognitive theory. Englewood Cliffs, NJ: Prentice-Hall.

Blanchard, M. R., Southerland, S. A., \& Granger, E. M. (2009). No silver bullet for inquiry: Making sense of teacher change following an inquiry-based research experience for teachers. Science Education, 93(2), 322-360.

Crawford, B. A. (2007). Learning to teach science as inquiry in the rough and tumble of practice. Journal of Research in Science Teaching, 44(4), 613-642.

Damnjanovic, A. (1999). Attitudes toward inquiry-based teaching: Differences between preservice and in-service teachers. School Science and Mathematics, 99(2), 71-76.

Dedoose (Version 5.0.11) [Computer Software]. Available from http://www.dedoose.com/

Dubner, J., Silverstein, S. C., Carey, N., Frechtling, J., Busch-Johnsen, T., Han, J., ... \& Zounar, E. (2001). Evaluating science research experience for teachers programs 
and their effects on student interest and academic performance: A preliminary report of an ongoing collaborative study by eight programs. MRS Proceedings, 684(1), GG3-6.

Enderle, P., Dentzau, M., Roseler, K., Southerland, S., Granger, E., Hughes, R., ... \& Saka, Y. (2014). Examining the influence of RETs on science teacher beliefs and practice. Science Education, 98(6), 1077-1108.

Fine, S. F., \& Glasser, P. H. (1996). The first helping interview: Engaging the client and building trust. Thousand Oaks, CA: SAGE Publications.

Fishbein, M. \& Ajzen, I. (1975). Belief, attitude, intention, and behavior: An introduction to theory and research. Reading, MA: Addison-Wesley.

Gibson, H. L., \& Chase, C. (2002). Longitudinal impact of an inquiry-based science program on middle school students' attitudes toward science. Science Education, 86(5), 693-705.

Gupta, R. (2012). Values and value system. Indian Journal of Positive Psychology, 3(4), 471-473.

Halverson, R., \& Clifford, M. (2013). Distributed instructional leadership in high schools. Journal of School Leadership, 23(2), 389-419.

Haney, J. J., Czerniak, C. M. and Lumpe, A. T. (1996). Teachers beliefs and intentions regarding the implementation of science education reform strands. Journal of Research in Science Teaching, 33(9), 971-994.

Harwood, W. S., Hansen, J., \& Lotter, C. (2006). Measuring teacher beliefs about inquiry: The development of a blended qualitative/quantitative instrument. Journal of Science Education and Technology, 15(1), 69-79. 
Hawkey, K. (1996). Image and the pressure to conform in learning to teach. Teaching and Teacher Education, 12(1), 99-108.

Helms, J. V. (1998). Science-and me: Subject matter identity in secondary school science teachers. Journal of Research in Science Teaching, 35(7), 811-834.

Kagan, D.M. (1992). Implications of research on teacher belief. Educational Psychologist, 27(1), 65-90.

Koballa, T. R., \& Crawley, F. E. (1985). The influence of attitude on science teaching and learning. School Science and Mathematics, 85(3), 222-232.

Kvale, S. (1994). Ten standard responses to qualitative research interviews. Journal of Phenomenological Psychology, 25(2), 147-173.

Lakin, J. M., \& Wallace, C. S. (2015). Assessing dimensions of inquiry practice by middle school science teachers engaged in a professional development program. Journal of Science Teacher Education, 26(2), 139-162.

Lewis, H. (1990). A question of values. San Francisco, CA: Harper \& Row.

Lotter, C., Harwood, W. S., \& Bonner, J. J. (2007). The influence of core teaching conceptions on teachers' use of inquiry teaching practices. Journal of Research in Science Teaching, 44(9), 1318-1347.

Luft, J. A., \& Roehrig, G. H. (2007). Capturing science teachers' epistemological beliefs: The development of the teacher beliefs interview. Electronic Journal of Science Education, 11(2). 38-63.

Mansour, N. (2008). The experiences and personal religious beliefs of Egyptian science teachers as a framework for understanding the shaping and reshaping of their 
beliefs and practices about science-technology and society (STS). International Journal of Science Education, 30(12), 1605-1634.

Marlow, M. P., \& Stevens, E. (1999). Science teachers attitudes about inquiry-based science. Retrieved from ERIC database. (No. ED466350)

Merriam, S. B. (2002). Qualitative research in practice: Examples for discussion and analysis. San Francisco, CA; Jossey-Bass.

Nespor, J. (1987). The role of beliefs in the practice of teaching. Journal of Curriculum Studies, 19(4), 317-328.

NGSS Lead States. (2013). Next generation science standards: For states, by states. Washington, DC: The National Academies Press.

Nisbett, R., \& Ross, L. (1980). Human inference: Strategies and shortcomings of social judgment. Englewood Cliffs, NJ: Prentice-Hall.

Pajares, M. F. (1992). Teachers' beliefs and education research: Cleaning up a messy construct. Review of Educational Research, 62(3), 307-332.

Park, S., Jang, J. Y., Chen, Y. C., \& Jung, J. (2011). Is pedagogical content knowledge (PCK) necessary for reformed science teaching?: Evidence from an empirical study. Research in Science Education, 41(2), 245-260.

Patton, M. Q. (2002). Qualitative research \& evaluation methods. Thousand Oaks, CA: Sage.

Peterman, F. P. (1991, April). An experienced teacher's emerging constructivist beliefs about teaching and learning. Retrieved from ERIC database. (No. ED336344) 
Pop, M. M., Dixon, P., \& Grove, C. M. (2010). Research experiences for teachers (RET): motivation, expectations, and changes to teaching practices due to professional program involvement. Journal of Science Teacher Education, 21(2), 127-147.

Raudenbush, S. W., Rowan, B., \& Cheong, Y. F. (1992). Contextual effects on the selfperceived efficacy of high school teachers. Sociology of Education, 65(2), 150167.

Richardson, V. (1996). The role of attitudes and beliefs in learning to teach. In J. Sikula \& T. J. Buttery \& E. Guyton (Eds.), Handbook of research on teacher education (pp. 102-119). New York, NY: Macmillan.

Rokeach, M. (1960). The open and closed mind. New York, NY: Basic.

Rokeach, M. (1968). Beliefs, attitudes, and values: A theory of organization and change. San Francisco, CA: Jossey-Bass.

Rokeach, M. (1973). The nature of human values. New York, NY: The Free Press.

Rokeach, M. (1979). Some unresolved issues in theories of beliefs, attitudes, and values. Nebraska Symposium on Motivation, 27, 261-304. Lincoln, NE: University of Nebraska Press.

Russell, S. H., \& Hancock, M. P. (2007). Evaluation of the research experiences for teachers (RET) program: 2001-2006. Menlo Park, CA: SRI International.

Sawada, D., Piburn, M. D., Judson, E., Turley, J., Falconer, K., Benford, R., \& Bloom, I. (2002). Measuring reform practices in science and mathematics classrooms: The reformed teaching observation protocol. School Science and Mathematics, 102(6), 245-253. 
Schwartz, S. H. (1994). Are there universal aspects in the structure and contents of human values? Journal of Social Issues, 50(4), 19-45.

Supovitz, J. A., \& Turner, H. M. (2000). The effects of professional development on science teaching practices and classroom culture. Journal of Research in Science Teaching, 37(9), 963-980.

Westerlund, J. F., García, D. M., Koke, J. R., Taylor, T. A., \& Mason, D. S. (2002). Summer scientific research for teachers: The experience and its effect. Journal of Science Teacher Education, 13(1), 63-83.

Wilson, S. M. (2013). Professional development for science teachers. Science, 340(6130), 310-313.

Zacharia, Z. (2003). Beliefs, attitudes, and intentions of science teachers regarding the educational use of computer simulations and inquiry-based experiments in physics. Journal of Research in Science Teaching, 40(8), 792-823. 


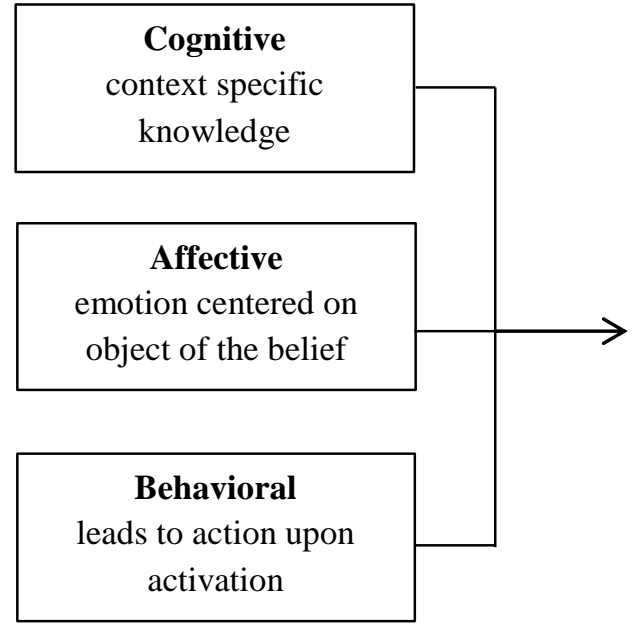

Attitude- a relatively enduring organization of beliefs around an object or situation predisposing an

Belief- a cluster of propositions related to a specific context or to knowledge that can create predispositions to actions individual to respond in some preferential manner

Value- a single belief that transcendentally guides an individual's actions and judgments across specific objects and situations and beyond immediate goals to achieve more ultimate, lifetime goals

Figure 1. Adaptation of Pajares's (1992) and Rokeach's (1968) conceptualization of an individual's belief sub-system. 
- Describes no changes in their inquiry-related knowledge, feelings, or behaviors
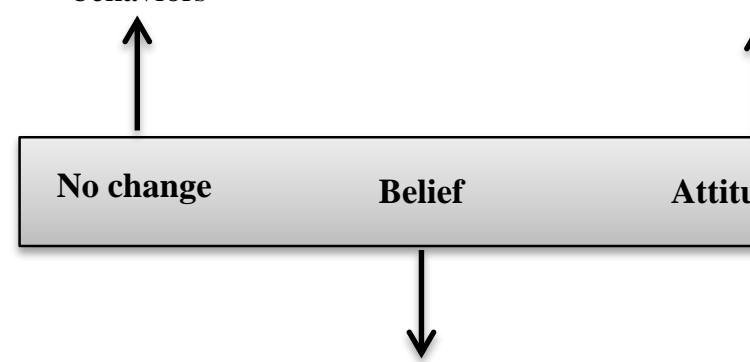

- Uses statements that clearly indicate better alignment of their knowledge with inquiry/scientific process

\section{and/or}

- Describes using more behaviors that reflect inquiry-based processes, but use of these behaviors is inconsistent
- Characteristics of attitude change

- Describes implementation of strategic actions to change practices of other teachers

- Actions implemented related to long- term vision for school or district

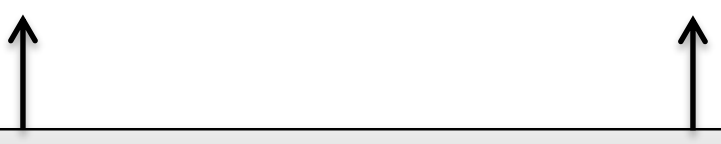


Table 1

Cohort 4 Participant and School Data (greatschools.org ${ }^{\dagger}$ )

\begin{tabular}{|c|c|c|c|c|c|c|c|c|}
\hline \multirow[b]{2}{*}{$\begin{array}{c}\text { Teacher } \\
\#\end{array}$} & \multicolumn{4}{|c|}{ Teacher demographics (2012) } & \multicolumn{2}{|c|}{ School demographics (2011) } & \multicolumn{2}{|c|}{$\begin{array}{c}\text { School achievement } \\
\left(2011 \mathrm{MEAP}^{1} / \mathrm{MME}^{2}\right)\end{array}$} \\
\hline & $\begin{array}{c}\text { Years } \\
\text { Experience }\end{array}$ & Gender & School \# & Subject & $\begin{array}{c}\text { Economically } \\
\text { Disadvantaged } \\
(\%)\end{array}$ & $\begin{array}{l}\text { Non- } \\
\text { White } \\
(\%)\end{array}$ & Math $(\%)$ & Science $(\%)$ \\
\hline & & & $\begin{array}{l}\text { State of } \\
\text { MI }\end{array}$ & & 35.40 & 29.20 & $52 / 78$ & $62 / 78$ \\
\hline 1 & 2 & $\mathrm{~F}$ & 1 & $\begin{array}{l}\text { 8th Grade Earth } \\
\text { Science }^{3}\end{array}$ & 53 & 25 & 82 & 83 \\
\hline 2 & 1 & M & 2 & $\begin{array}{l}\text { 6th and 7th Grade } \\
\text { Science }\end{array}$ & 34 & 21 & 84 & 83 \\
\hline 3 & 22 & M & 3 & 8th Grade Physics ${ }^{3}$ & 27 & 8 & 89 & 89 \\
\hline 4 & 12 & M & 3 & 8th Grade Physics ${ }^{3}$ & 27 & 8 & 89 & 89 \\
\hline 5 & 26 & $\mathrm{~F}$ & 4 & 6th Grade Science & 31 & 7 & 84 & 86 \\
\hline 6 & 22 & M & 5 & 6th Grade Science & 46 & 42 & 83 & 85 \\
\hline 7 & 6 & M & 6 & $\begin{array}{c}\text { Extension Science } \\
\text { Programs }\end{array}$ & 62 & 5 & 79 & 81 \\
\hline 8 & 6 & $\mathrm{~F}$ & 7 & MS Earth Science & 14 & 4 & 93 & 92 \\
\hline 9 & 17 & $\mathrm{~F}$ & 8 & Biology & 18 & 14 & 69 & 67 \\
\hline 10 & 17 & $\mathrm{~F}$ & 9 & $\begin{array}{l}\text { Biology, Chemistry } \\
\text { and Forensics }\end{array}$ & 31 & 17 & 74 & 65 \\
\hline $11^{*}$ & 8 & $\mathrm{~F}$ & 10 & $\begin{array}{l}\text { Agricultural } \\
\text { Science }\end{array}$ & & & & \\
\hline 12 & 10 & $\mathrm{~F}$ & 11 & $\begin{array}{l}\text { Physics and } \\
\text { Chemistry }\end{array}$ & 26 & 11 & 71 & 61 \\
\hline $13 * *$ & 5 & M & 12 & $\begin{array}{c}\text { Chemistry and } \\
\text { Biology }\end{array}$ & & & & \\
\hline
\end{tabular}

${ }^{\dagger}$ greatschools.org offers an aggregation of state reported data for schools across the US. The website continues to offer this aggregated statistical data, although it is now more difficult to locate. After searching for/selecting a school, click on the Report Card tab to see state report card data.

${ }^{1}$ MEAP $=$ Michigan Educational Assessment Program and is administered to middle school students in $8^{\text {th }}$ grade. ${ }^{2}$ MME $=$ Michigan Merit Exam and is administered to high school students. ${ }^{3}$ Teacher in middle school setting, but teaches high school curriculum. *Denotes vocational school, some data not published. **Denotes private school, some data not published. 
Table 2

Brief Outline of RET Timeline and Activities

\begin{tabular}{|c|c|}
\hline 胥 & $\begin{array}{l}\text { Preparation to do Research } \\
\text {-Start reading science literature } \\
\text {-Introduction to research projects }\end{array}$ \\
\hline
\end{tabular}

\section{Research Experience}

-Work with science mentor reviewing literature, mastering laboratory techniques, collecting and analyzing data -Write a final paper and present a poster summarizing research project.

\section{Connecting Research to Practice}

Weekly meetings with cohort teachers to:

-Debrief research experience with respect to how it relates to classroom instruction

-Identify changes to be made in existing activities to incorporate processes of science based on the RET

-Modify two activities for implementation in their classroom 
Table 3

Categorization of Teacher Change and Statements Representative of Change

\begin{tabular}{|c|c|c|}
\hline Change & Teacher Statements & $\begin{array}{l}\text { Teachers with } \\
\text { Change }\end{array}$ \\
\hline Belief & $\begin{array}{l}\text { Part of it is wanting students to like science, it's probably the- one of the larger } \\
\text { things. I think at the same time also wanting to like my own job, so really } \\
\text { those two things could probably describe most of my motivation, because I } \\
\text { think that students tend to not enjoy or not understand science if they're only } \\
\text { taking notes and taking tests and checking off objectives (Teacher 13) }\end{array}$ & Teacher \# 13 \\
\hline Attitude & $\begin{array}{l}\text { I would say my goal is always to continue to improve how I teach and make it } \\
\text { as beneficial to my students as I can. I think inquiry has a ton of value to it, so } \\
\text { it's something that I believe will help me to be a better teacher if I can } \\
\text { implement more of that into my classroom. I think it reflects on how kids } \\
\text { think. (Teacher 9) }\end{array}$ & $\begin{array}{c}\text { Teachers \# 5-7, } \\
9-12\end{array}$ \\
\hline Attitude/ Value & $\begin{array}{l}\text {..I want to make sure that it's good science, that there's integration of STEM, } \\
\text { that it has meat to it, it's not just activities that kind of go together, that it's a } \\
\text { curriculum that you do and it's not going to help our students at all. And so I } \\
\text { think that just making sure that it's going to be a program that's going to last, } \\
\text { and that if I'm not in [this school] forever then somebody else can pick it up } \\
\text { and it's never something that leaves. (Teacher 1) }\end{array}$ & $\begin{array}{c}\text { Teachers \# 1, 3, } \\
8\end{array}$ \\
\hline Value & $\begin{array}{l}\text {... The labs that we used- [Teacher 3] and I kind of modified a big- a larger } \\
\text { group of them [lesson plans] together so that we had our whole first marking } \\
\text { period kind of ready to go... [Teacher 3] and I felt- and [a comparison teacher] } \\
\text { too- because he liked what we were doing, and [the comparison teacher] } \\
\text { really kind of always taught this way anyways, so when we started teaching } \\
\text { this, the district also took on a partnership... to do the same thing. [We] had } \\
\text { already started it and we were already teaching that way. That's one of the } \\
\text { pieces I put in my own evaluation is that the eighth grade science department } \\
\text { is kind of leading the charge on inquiry implementation in the district. } \\
\text { (Teacher 4) }\end{array}$ & Teachers \# 2, 4 \\
\hline
\end{tabular}


Table 4

Various Aspects of Teacher Inquiry-related Beliefs Influenced by RET

\begin{tabular}{|c|c|c|}
\hline $\begin{array}{c}\text { Inquiry-related } \\
\text { Code }\end{array}$ & Representative Statements & $\begin{array}{c}\text { Frequency Count by } \\
\text { Type of Change }\end{array}$ \\
\hline $\begin{array}{l}\text { Enactment of } \\
\text { Inquiry-Based } \\
\text { Practice }\end{array}$ & $\begin{array}{l}\text { They communicate their findings with classmates and } \\
\text { the big thing I see with all of these is they are all } \\
\text { collaborating a lot. They are working together finding } \\
\text { things out reflecting on work together. Designing and } \\
\text { implementing appropriate procedures for different } \\
\text { investigations. (Teacher 2) }\end{array}$ & $\begin{array}{l}\text { Value: } 40 \\
\text { Attitude/Value: } 34 \\
\text { Attitude: } 51 \\
\text { Belief: } 7\end{array}$ \\
\hline $\begin{array}{l}\text { Pedagogical } \\
\text { Content } \\
\text { Knowledge }\end{array}$ & $\begin{array}{l}\text { I think the way it's different is that I think, especially } \\
\text { the younger the student, and the less experienced the } \\
\text { student, the more maybe structure and guidance has to } \\
\text { come along. It may be just leading at first and then } \\
\text { letting them go. Because maybe they don't know } \\
\text { where to start, or maybe they just need to know if the } \\
\text { information they are starting with is correct. (Teacher } \\
\text { 8) }\end{array}$ & $\begin{array}{l}\text { Value: } 20 \\
\text { Attitude/Value: } 25 \\
\text { Attitude: } 17 \\
\text { Belief: } 0\end{array}$ \\
\hline $\begin{array}{l}\text { Knowledge of } \\
\text { Inquiry-Based } \\
\text { Practice }\end{array}$ & $\begin{array}{l}\text {...the main thing is just giving up the control, and not } \\
\text { doing labs where I know what the outcome is already } \\
\text { going to be. I mean I've said to my students so many } \\
\text { times "I don't know, why don't you put it together } \\
\text { and figure it out, because I don't know the answer"... } \\
\text { I mean I could make a good guess on what's going to } \\
\text { happen, but I don't really know because they might be } \\
\text { investigating something that I've never done before. } \\
\text { (Teacher 1) }\end{array}$ & $\begin{array}{l}\text { Value: } 44 \\
\text { Attitude/Value: } 48 \\
\text { Attitude: } 80 \\
\text { Belief: } 8\end{array}$ \\
\hline
\end{tabular}


Table 5

Feature of RET Teachers Described as Influential to Their Science Instruction

\begin{tabular}{|c|c|c|}
\hline Influential Feature & Representative Teacher Statement & $\begin{array}{l}\text { Feature Frequency } \\
\text { Count vs. Type of } \\
\text { Change }\end{array}$ \\
\hline $\begin{array}{l}\text { Better } \\
\text { Understanding of } \\
\text { the Scientific } \\
\text { Process }\end{array}$ & $\begin{array}{l}\text { Science to me was a list of facts...so when I went } \\
\text { up there and saw how people do science and that } \\
\text { they didn't know everything, I guess I never put } \\
\text { two and two together that science still is evolving } \\
\text { and we still don't know everything...(Teacher } 4 \text { ) }\end{array}$ & $\begin{array}{l}\text { Value: } 15 \\
\text { Attitude/value: } 7 \\
\text { Attitude: } 57 \\
\text { Belief: } 3\end{array}$ \\
\hline $\begin{array}{l}\text { Weekly Debriefing } \\
\text { meeting: } \\
\text { Collaboration with } \\
\text { cohort teachers }\end{array}$ & $\begin{array}{l}\text {...you got to talk to everybody and find out how } \\
\text { their stuff is not going so well either or that } \\
\text { everybody had these hurdles that...they were trying } \\
\text { to work through. (Teacher 11) }\end{array}$ & $\begin{array}{l}\text { Value: } 5 \\
\text { Attitude/value: } 5 \\
\text { Attitude: } 13 \\
\text { Belief: } 4\end{array}$ \\
\hline $\begin{array}{l}\text { Weekly Debriefing } \\
\text { meeting: Lessons } \\
\text { on inquiry }\end{array}$ & $\begin{array}{l}\text { If I had just been given this model, and I hadn't } \\
\text { taken the inquiry classes that I've taken, then I } \\
\text { don't think I'd be using the model the same way. I } \\
\text { think I'd be using a template, and it would be just } \\
\text { like the scientific method. Which is what I hear my } \\
\text { teaching partners talk about all the time. It's just } \\
\text { like following the scientific method....I'm like not } \\
\text { quite. (Teacher 5) }\end{array}$ & $\begin{array}{l}\text { Value: } 19 \\
\text { Attitude/value: } 18 \\
\text { Attitude: } 8 \\
\text { Belief: } 0\end{array}$ \\
\hline $\begin{array}{l}\text { Weekly Debriefing } \\
\text { meeting: Material } \\
\text { adaptation }\end{array}$ & $\begin{array}{l}\text { I actually ended up modifying three... I have a } \\
\text { really, really low reading group this year, and so } \\
\text { that's really translated into their scientific ability... } \\
\text { And so, it's been interesting how I've had to not } \\
\text { only modify [the science lesson materials], but } \\
\text { also differentiate with some of my low, low, low } \\
\text { readers. (Teacher 8) }\end{array}$ & $\begin{array}{l}\text { Value: } 3 \\
\text { Attitude/value: } 2 \\
\text { Attitude: } 7 \\
\text { Belief: } 1\end{array}$ \\
\hline Poster Presentation & $\begin{array}{l}\text { The most valuable conversations that I had at the } \\
\text { poster deal was the ones that I had with the } \\
\text { professors from other colleges that were teaching } \\
\text { climate change. So to have the conversation of } \\
\text { why did you decide to do it this way...or why } \\
\text { would you do this with your students, or, so that } \\
\text { piece I felt like was really helpful. (Teacher 1) }\end{array}$ & $\begin{array}{l}\text { Value: } 2 \\
\text { Attitude/value: } 9 \\
\text { Attitude: } 8 \\
\text { Belief: } 0\end{array}$ \\
\hline
\end{tabular}


Appendix

Final Operationalized Codes Used to Examine Teacher Knowledge, Feelings, and Behavior Related to Inquiry-based Instruction

\section{Code: Knowledge of Inquiry-based Practice}

Teacher statements reflect accurate knowledge related to their science content area (content knowledge), what inquiry-based practices are (technical knowledge), how/why they are (or can be used as) best practices for science instruction (conceptual knowledge), and how the implement these practices in way that would support learning based on student needs (pedagogical content knowledge).

\section{Sub-codes}

Conceptual. Teacher appropriately use of terms/definitions of inquiry related practices. E.g., teacher appropriately uses terms such as small groups, hands-on, studentcentered/controlled, etc. that reflect a constructivist approach to student learning.

Technical. Teacher describes activities related to designing and/or implementation of inquiry in lessons/NGSS science practices. E.g., teacher introduces a problem to students then breaks them into small groups where students, with teacher in a facilitator role, plan an experimental design to explore the problem.

Subject/content knowledge. Teacher statements reflect a good/strong grasp of their

content area. E.g. teacher coherently describes a scientific concept covered in their classroom.

Pedagogical content knowledge. Teacher expresses an ability to discern which pedagogical techniques would be an effective strategy to help students grasp content. E.g. teacher discusses strategically what their discussions, student activities, or lesson plans should 
Table 4

Statements Reflecting Teacher Feelings about Inquiry after RET

\begin{tabular}{|c|c|c|}
\hline $\begin{array}{c}\text { Inquiry-related } \\
\text { Code }\end{array}$ & Representative Statements & $\begin{array}{c}\text { Frequency Count by } \\
\text { Type of Change }\end{array}$ \\
\hline $\begin{array}{l}\text { Positive } \\
\text { Emotions about } \\
\text { Inquiry }\end{array}$ & $\begin{array}{l}\text {... so there was the radiation lab that I modified, } \\
\text { because it completely bombed last year and why not } \\
\text { just let the kids have free range with it, and that was } \\
\text { really cool to see what they did this year. (Teacher 5) }\end{array}$ & $\begin{array}{l}\text { Value: } 22 \\
\text { Attitude/Value: } 34 \\
\text { Attitude: } 99 \\
\text { Belief: } 9\end{array}$ \\
\hline $\begin{array}{l}\text { Neutral } \\
\text { Emotions about } \\
\text { Inquiry }\end{array}$ & $\begin{array}{l}\text { I felt like [being a scientist] was maybe more, a little } \\
\text { more social than I realized....so there was a lot of } \\
\text { interaction with people and I think I had a lot more } \\
\text { sterile view of somebody being in a cubicle and not } \\
\text { talking to anybody else. (Teacher 10) }\end{array}$ & $\begin{array}{l}\text { Value: } 2 \\
\text { Attitude/Value: } 2 \\
\text { Attitude: } 2 \\
\text { Belief: } 1\end{array}$ \\
\hline $\begin{array}{l}\text { Negative } \\
\text { Emotions about } \\
\text { Inquiry }\end{array}$ & $\begin{array}{l}\text {...it almost felt like, to be a scientist you need to be } \\
\text { married to your science. I'm sure that's probably the- } \\
\text { like most things, the greats, the great scientists of } \\
\text { today really are and that's all they think about, that's } \\
\text { all they care about, that's all they do and in a similar } \\
\text { way a lot of teachers too. (Teacher } 13 \text { ) }\end{array}$ & $\begin{array}{l}\text { Value: } 4 \\
\text { Attitude/Value: } 1 \\
\text { Attitude: } 8 \\
\text { Belief: } 11\end{array}$ \\
\hline
\end{tabular}


contain. May also include discussions about common misunderstandings students have and how they designed lessons to address student needs.

\section{Code: Positive Emotions about Inquiry}

Any teacher statement related to inquiry where the teacher expresses feeling words or make statements where the substitution of "I feel," can be made appropriately for a positive/good emotion. E.g. It was amazing to see each group of students find all unique but viable solutions to the same problem.... can become... [I feel] it was amazing to see each group of students find all unique but viable solutions

\section{Code: Neutral Emotions about Inquiry}

Any teacher statement related to inquiry where the teacher expresses feeling words or make statements where the substitution of "I feel," can be made appropriately for a neutral emotion. E.g. It was interesting to see the experiments students designed on their own.

\section{Code: Negative Emotions about Inquiry}

Any teacher statement in which the teacher expresses feeling words or make statements negative/bad emotion about inquiry. E.g. I feel overwhelmed when I try to have students design their own experiments.

\section{Code: Intended Enactment of Inquiry-based Behavior}

Teacher expressed future plans to use inquiry-based instruction. E.g. I will... I plan..., I want... I hope ..., etc. to have students design their own experiments

\section{Enactment of Inquiry-based Behavior}

Teacher describes specific ways they have used inquiry-based practices. E.g. teacher discusses a lesson that had characteristics of inquiry including: students asking testable, standards-aligned questions, developing and/or using models, planning and implementing 
investigations, constructing explanations, engaging in evidence based small group and whole class debate and discussion, using everyday materials.

\section{Code: Influential Feature of RET}

Any experience teacher refers to as useful, valuable, insightful that they directly or indirectly relates with RET that has influenced teachers' instruction. Including the 6-week research experience with mentor, weekly debriefing meetings, poster presentation.

\section{Code: Influential Feature NOT Related to RET}

Any experience teacher refers to as useful, valuable, or insightful to their that is not related in any way to RET activities/requirements, but has influenced their instruction since the RET. E.g. Teacher describes an event prior to, during, or after RET in their personal life or a district policy change that has influenced what, how, or why they have changed their instruction in the academic past year since the RET.

\section{Code: Absence/Removal/Reduction of Barrier}

Any indication that sociocultural or infrastructure challenges have been removed or reduced. E.g. district has moved away from pencil/paper testing towards project-based work. Fellow teacher(s) within school setting have agreed to support inquiry in their own classrooms or in TI teacher's classroom (may just have indicated interest in TI teacher's strategies/lesson plans).

\section{Code: Presence of barrier}

Any indication that sociocultural or infrastructure challenges persist or have emerged.

E.g. extensive time needs to be spent on testing or common assessments that do not align with inquiry-based instruction or no support from fellow teachers or administration. 